\title{
複視に対するプリズム適応の検討
}

稲垣理佐子・浅野 麻衣・正木勢津子・彦谷 明子・堀田 喜裕 佐藤 美保

浜松医科大学眼科

\section{Indications of prism prescription for diplopia}

\author{
Risako Inagaki, Mai Asano, Setsuko Masaki, Akiko Hikoya, \\ Yoshihiro Hotta, Miho Sato
}

Department of Ophthalmology, Hamamatsu University School of Medicine

要 約

\section{【複視に対するプリズム適応の検討】}

〈目的〉処方されたプリズムに満足した症例としなかった症例を比較することによって、不満 足であった原因を検討する。

〈対象と方法〉平成 15 年 1 月〜平成 17 年 5 月に複視を主訴に浜松医科大学眼科を受診した 20 歳以上 の患者、総数144名のうち眼位の記載が不十分のもの、追跡ができなかったものを除く86名を対象 とした。

プリズム眼鏡を処方され満足した適応群と処方を受けなかったか、受けても不満足であった不適応 群に分け性別、年齢、診断、視力、眼位、について検討した。

〈結 果〉86名のうち、自然治癒は 12 名、適応群は33名、不適応群はプリズム処方で不満足 17 名 および手術 24 名をあわせた 41 名であった。水平、回旋斜視角で適応群、不適応群の二群間に有意差 はなかったが、上下斜視角では有意差を認めた。また、上斜筋麻痺では、年齢および上下斜視角で 有意差を認めたが、上斜筋麻瘏以外で有意差は認められなかった。

〈結＼cjkstart論〉プリズムを勧めて満足できたものは対象者の半数以下であった。また、プリズムに適 応できるかどうかは上下斜視角の程度に強く影響された。疾患別では、若年齢の上斜筋麻痺患者は 斜視角が大きく、プリズムに満足しないことが多かったが、上斜筋麻瘏以外では二群間に統計的に 明らかな要因は認められず、症例ごとにトライアルをする必要があると思われた。

別冊請求先（广431-3192）浜松市半田山 $1-20-1$

Tel. 053-435-2656 Fax. 053-435-2656

Key words : prism prescription, diplopia, superior oblique palsy

プリズム処方、複視、上斜筋麻痺 


\begin{abstract}
Purpose

To clarify the reasons of dissatisfaction for prisms by means of comparing the cases who were successfully treated with prisms and the cases who were not.

Subjects and Methods

This is a retrospective chart review.

The patients older than 20 years, who visited Hamamatsu university school of medicine, department of Ophthalmology with a chief complaint of diplopia between January 2003 and May 2005 were studied. Within 144 patients, the patients with insufficient records of eye positions and the patients who were not followed were excluded. The remaining 86 cases were studied.

The patients were divided into two groups: 1) adaptation: who were satisfied with prisms, and 2) nonadaptation: who were not satisfied with prisms. Gender, age, diagnosis, vision, and ocular deviations were compared between the two groups.
\end{abstract}

\title{
Results
}

Twelve patients did not require prisms because of little trouble and they were excluded from the study. Thirty-three patients were adapted to the prisms. Seventeen patients did not satisfy prisms regardless they were prescribed prisms, and 24 patients underwent strabismus surgery. A total of 41 patients were classified to the non-adapted group.

There were no significant differences between the two groups in age, gender, the amount of horizontal deviation and the amount of torsional deviation. Only the vertical deviation was significantly larger in non-adapted group than in the adapted group (near: $\mathrm{p}<0.001$, far: $\mathrm{p}<0.0001$ ). Among the patients with superior oblique palsy, the amount of vertical deviation was larger and the patients were younger in the non-adapted group. These findings were not observed in the patients without superior oblique palsy,

\section{Conclusions}

Less than a half of patients satisfied with prisms. The patients 1 satisfaction was strongly influenced by the amount of vertical deviation. Young patients with superior oblique palsy were unlikely to satisfy with the prisms. It is difficult to speculate the patients who may satisfy with prisms or not. Therefore we need to try prisms on each patient.

\section{I ．緒言}

複視の治療には手術、視能訓練、光学的治療 などがあるが、当院では光学的治療であるプリ ズム眼鏡を最初に勧めている。しかしプリズム 処方には多くの時間と労力がかかり、作成して も使っていないという症例も少なくない。これ までにプリズム処方で満足な結果を得た症例を 検討した報告はあるが1)21、満足と不満足な症 例の境界についての情報はあまり見受けられな い。そこで、複視を主訴に来院した患者のうち プリズムに満足した症例と、満足しなかった症 例を比較検討することによって、プリズムに適 応しやすい症例とそうでない症例をあらかじめ 予測することが可能になるのではないかと考え
た。

本論文の目的は、プリズム装用を勧める患者 選択の参考值を求めることである。

\section{II . 対象および方法}

<対 象 >

平成15年 1 月〜平成 17 年 5 月に複視を主訴に 浜松医科大学眼科を受診した 20 歳以上の患者を、 病院の患者情報管理システムを利用して抽出し た。144名が抽出されたが、そのうち、眼位の 記載が不十分なもの、追跡不可能であったもの を除く86名を対象とした。プリズム眼鏡につい て説明を受けたのち、不自由度が少ないために プリズム処方を受けずに自然治癒した 12 名は対 
象から除き、74名を以下の方法で二群に分け検 討した。対象の振り分けをフローチャートにし て図 1 に示す。プリズムに関する説明を受けた

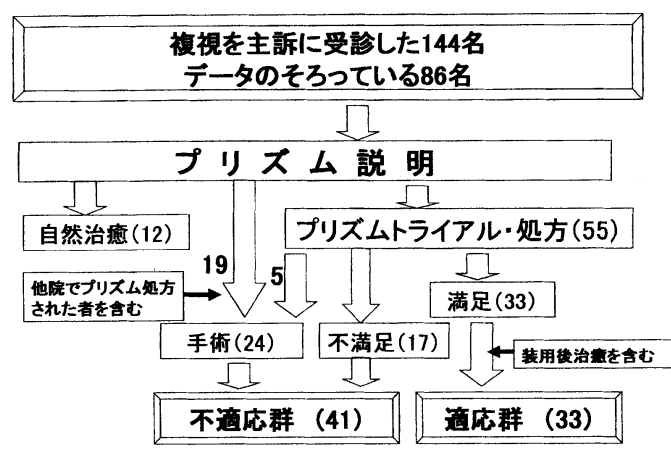

図 1 対象の振り分け方法

対象をフローチャートに従って、適応群と不適 応群に振り分けた。数字は人数を示す。

段階でプリズム望まなかったのは19名で、残り の55名にトライアルを行った。プリズム処方を 受け、再診時にもプリズムを装用していたもの は33名であり、適応群とした。その中には装用 後に治癒したものも含んでいる。プリズム処方 を望まず手術を受けたもの19名、プリズム処方 を受けたが不満足でその後手術を受けたもの5 名、トライアルの段階で満足が得られなかった か、処方を受けたがプリズムを装用していなか ったもの17名の合計41名を不適応群とした。

$<$ 方法 1 全体での検討 $>$

上記の基準で分けた適応群と不適応群の二群 間で、性別、年齢、診断、視力、眼位について 検討し、有意差検定はMann-Whitney's U test を用い、危険率（p）0.05以下を有意差ありと した。

$<$ 方法 2 上斜筋麻痺と甲状腺眼症での検討 $>$

刘象となった症例の中から、症例数の多かっ た上斜筋麻痺と甲状腺眼症の患者を抽出し、そ れぞれの中の適応群と不適応群の二群間で、年 齢、眼位をMann-Whitney's U testを用いて検 討した。

\section{III. 結果}

\section{$<1$. 全体での検討 $>$}

疾患別に適応者と不適応者の数を示す。（表 1 ） 適応群と不適応群の間に、性別、年齢、視力 に有意差は認められなかった。(表 2)

適応群の遠見の水平斜視角は $40 \Delta$ 内斜視 $18 \Delta$ 外斜視、近見の水平斜視角は $25 \Delta$ 内斜視〜 $25 \Delta$ 外 斜視で上下斜視角は遠見、近見とも最高14 $\Delta$ であ った。実際に処方され、満足がえられた水平方向 のプリズム度数は平均 $10.42 \Delta て ゙$ 範囲は $4 \Delta \sim 21 \Delta$ 、

表 1 対象となった症例の疾患名と人数

\begin{tabular}{|c|c|c|c|}
\hline 疾患名 & $\begin{array}{c}\text { 症例数 } \\
\text { (適応群) }\end{array}$ & 疾患名 & $\begin{array}{c}\text { 症例数 } \\
\text { (適応群) }\end{array}$ \\
\hline 上斜筋麻㾝 & $18(6)$ & 下直筋麻㾝 & $3(2)$ \\
\hline 甲状腺眼症 & $9(4)$ & Brown 症候群 & $2(1)$ \\
\hline 外転神経麻㾝 & $5(2)$ & 外斜視 & $2(2)$ \\
\hline 糖尿病性眼筋麻瘪 & $4(3)$ & 脳幹梗塞 & $2(1)$ \\
\hline 網膜回転術後 & $4(0)$ & 開散麻疸 & $1(0)$ \\
\hline 眼窩底骨折 & $4(1)$ & 下斜筋過動 & $1(0)$ \\
\hline Skew deviation & $3(0)$ & 不明 & $14(11)$ \\
\hline
\end{tabular}

数字は左に全体を、括弧内にプリズムに適応した人数を示す。

表 2 適応群と不適応群の性別、年齢、視力

\begin{tabular}{|c|c|c|c|}
\hline \multicolumn{2}{|c|}{} & 適応群 & 不適応群 \\
\hline \multicolumn{2}{|c|}{ 人数(名) } & 33 & 41 \\
\hline \multirow{2}{*}{ 性 } & 男性(名) & 23 & 25 \\
\cline { 2 - 4 } 女性(名) & 10 & 16 \\
\hline \multirow{2}{*}{ 年齢 (歳) } & $\begin{array}{c}32 \sim 79 \\
\text { (平均 59.7) }\end{array}$ & $\begin{array}{c}21 \sim 81 \\
\text { (平均 52.6) }\end{array}$ \\
\hline \multicolumn{2}{|c|}{ 視力 } & $\begin{array}{c}0.5 \sim 2.0 \\
\text { (中央値 1.5) }\end{array}$ & $\begin{array}{c}0.1 \sim 1.5 \\
\text { (中央值 1.2) }\end{array}$ \\
\hline
\end{tabular}

表 3 適応群の斜視角と処方されたプリズム度数

\begin{tabular}{|c|c|c|c|c|}
\hline \multicolumn{2}{|c|}{} & \multicolumn{2}{|c|}{ 範囲 } & \multicolumn{2}{c|}{ 処方プリズム } \\
\cline { 3 - 5 } & \multicolumn{2}{|c|}{ 平均 } & 範囲 \\
\hline \multirow{2}{*}{ 遠見 } & 水平 & $40 \mathrm{E} \mathrm{T} \sim 18 \mathrm{X} \mathrm{T}$ & 10.42 & $4 \sim 21$ \\
\cline { 2 - 5 }$(\triangle)$ & 上下 & $0 \sim 14$ & 3.3 & $1 \sim 5$ \\
\hline 近見 & 水平 & $25 \mathrm{E} \mathrm{T} \sim 25 \mathrm{X} \mathrm{T}$ & 10.42 & $4 \sim 21$ \\
\cline { 2 - 5 }$(\triangle)$ & 上下 & $0 \sim 14$ & 3.3 & $1 \sim 5$ \\
\hline
\end{tabular}

$\mathrm{ET}$ : 内斜視 $\mathrm{XT}:$ 外斜視 


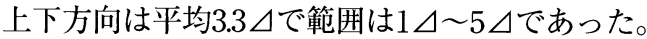
（表 3 ）不適応群の遠見の水平斜視角は $45 \Delta$ 内斜 視 $50 \Delta$ 外斜視、近見の水平斜視角は $40 \Delta$ 内斜視 〜 50 $\Delta$ 外斜視で上下斜視角は遠見、近見とも0

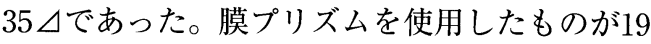
名、組み込みプリズムが14名、膜プリズムの最高 が21ム、組み込みプリズムの最高は左右合わせて

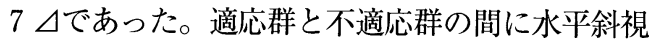
角の有意差は見られなかった。しかし上下斜視角 の遠見、近見は不適応群の斜視角が大きくなって いた。（p<0.001）（図 2）

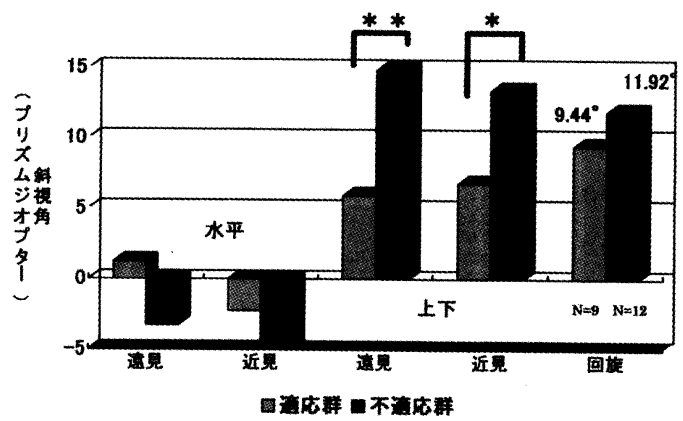

図 2 適応群、不適応群の斜視角と回旋偏位度 遠見、近見の水平と上下斜視角の平均を、適 応群と不適応群に分けて示す。回旋偏位度の 平均を適応群と不適応群に分けて示す。 * : $\mathrm{p}<0.001$

**: $\mathrm{p}<0.0001$ (Mann-Whitney's U-test)

回旋複視を合併した21名のうち、プリズムで 満足が得られたのは 9 名で範囲は $5{ }^{\circ} \sim 15^{\circ}$ であ った。そのうち 7 名は上下プリズムのみ、 1 名 は一眼に水平プリズム、他眼に上下プリズム、 1 名は $7 \Delta$ 基底 $30^{\circ}$ に貼ることで満足な結果が えられた。不適応群は12名で回旋偏位の範囲は $3^{\circ} \sim 30^{\circ}$ であった。不適応群 12 名のうち 8 名は 手術を受けた。適応群と不適応群の間に回旋偏 位の有意差は見られなかった。

$<2$. 上斜筋麻痺と甲状腺眼症での検討 $>$

上斜筋麻痺では適応群の年齢は $66.2 \pm 5.24$ 歳、 不適応群は $39.8 \pm 16.5$ 歳で不適応群が若く、上下 斜視角では適応群 $2.75 \pm 2.38 \Delta$ 、不適応群 $16.42 \pm$ $7.25 \Delta$ 、で適応群の斜視角が小さいことが判明 した。（p < 0.001）（表 4 )

甲状腺眼症では不適応群が適応群に比べて水
表 4 上斜筋麻痺の検討結果

\begin{tabular}{|c|c|c|}
\hline & 適応群 $(6$ 名) & 不適応群 (12 名) \\
\hline 年齡 (歳) & $66.2 \pm 5.24$ & $39.8 \pm 16.5$ \\
\hline 水平斜視角 $(\triangle)$ & $-3.67 \pm 3.50$ & $-8.92 \pm 12.01$ \\
\hline 上下斜視角 $(\triangle)$ & $2.75 \pm 2.38$ & $16.42 \pm 7.25$ \\
\hline 回旋偏位 $\left(^{\circ}\right)$ & $7.67 \pm 2.51$ & $7.67 \pm 6.43$ \\
\hline
\end{tabular}

* : P<0. 01 (Mann-Whitney' s U test)

表 5 甲状腺眼症の検討結果

\begin{tabular}{|c|c|c|}
\hline & 適応群 $(4$ 名) & 不適応群 $(5$ 名 $)$ \\
\hline 年齢 (歳) & $51.0 \pm 4.64$ & $69.8 \pm 8.53$ \\
\hline 水平斜視角 $(\triangle)$ & $-6.38 \pm 6.67$ & $3.40 \pm 24.02$ \\
\hline 上下斜視角 $(\triangle)$ & $8.00 \pm 2.12$ & $16.60 \pm 14.11$ \\
\hline
\end{tabular}

いずれも有意差なし

平、上下斜視角ともに大きい傾向がみられたが、 有意差は認められなかった。（表 5 ）

\section{IV. 考按}

今回の調査では水平斜視角よりも上下斜視角 が遠見、近見とも不適応群で大きくなっており、 適応と不適応群を分ける大きな要因となってい た。その理由について考按する。まず、上下斜 視では代償頭位のとりにくさがある。水平斜視 でとる代償頭位（顔の回し）よりも上下斜視で とる垂直の代償頭位（顎の上げ下げ）は不自然 な姿勢であり不自由度が高いことから、手術を 選択することが多いと思われた。次に、高い度 数の垂直プリズムを装用すると、プリズムを通 して見える眼球の高さが左右でずれるため、美 容的に問題になると思われた ${ }^{3)}$ 。(図 3 )

今回の対象にはさまざまな眼球運動障害が含 まれており、各疾患別の症例数は少ないために 疾患別の特徵を引き出すには至らなかった。し かし、上斜筋麻瘏では適応群 6 名に対し不適応 群12名と不適応群が多く、年齢と斜視角におい て有意差が現れた。若年性の上斜筋麻疩は先天 性、あるいは長期にわたる特発性麻痺のことが 多く、加齢により融像が破錠して複視を自覚す 


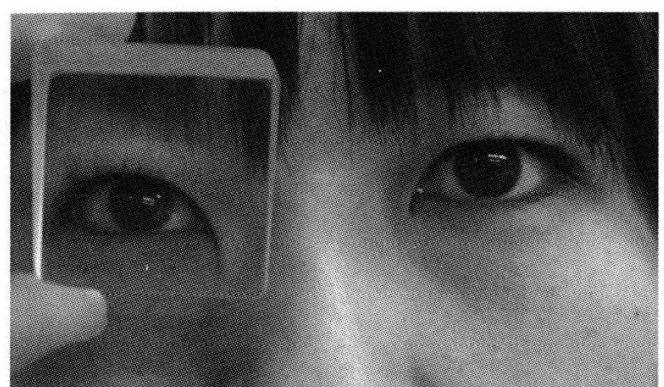

図 3 健常者に $20 \Delta$ を基底 $90^{\circ}$ に装用した場合 プリズムを右眼前に基底上方に装用すると右 眼が左眼に比べて下方向にずれているように 見えるため、外見的に問題となる。

る。年齢も平均 30 歳代と若く、自然治癒が望め ないとわかった時点で、手術による根治術を望 んだと考えられる。それに対し、中高年者の上 斜筋麻盘は脳血管障害や外傷による滑車神経麻 疩であり、前者とは異なる機序と考えてよい。

今回、満足して装用できたプリズム度数の平 均は水平方向 $10.42 \Delta$ 、上下方向 $3.3 \Delta$ と予想より 低いものであった。組み込み式では $3 \sim 5 \Delta ま$ で（特注は除く）、膜プリズムでは $1 \sim 40 \Delta$ の 処方が可能である。組み込み式は処方範囲が狭 く度数の変更が容易ではないが、外見的に比較 的目立たないこと、耐久性があることが利点で ある。一方膜プリズムの利点として広範囲にわ たって処方が可能であり、安価で取り外しが自 由にでき、症状の変化に対応しやすいことが挙 げられる。しかし12 $\Delta$ 以上では視力低下をきた すこと ${ }^{4)}$ 、高い度数では線が外見上目立つこと などが難点として報告されている ${ }^{3)}$ 。今回処方 された水平の膜プリズムの最高が左右合わせて

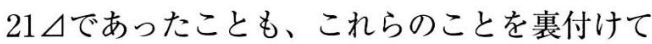
いると思われる。

一旦外来でプリズムを処方しても継続して使 っているとは限らない。その原因を理解するこ とは今後のプリズム処方の適岕者を知る上で重 要であろう。実際、今回の調査ではプリズムを

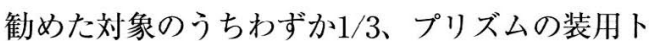
ライアルを行ったうちの $1 / 2$ がプリズムに満足
しただけであった。

今回、プリズムに適応しやすい症例とそうで ない症例を事前に知ることができれば、処方の ために費やす時間と労力を軽減できるのではな いかと期待して調查を行った。重度の動眼神経

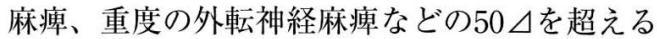
ような大角度の斜視、抑制があり複視の自覚の ない症例は含まれていない。また今回の調査は 前向き試験でなく、カルテからの後ろ向き調査 であったことから、水平、上下方向のプリズム に適応できる最大值を求めることは不可能であ

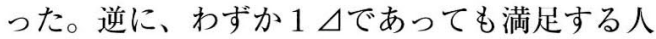
が你在することから、上下プリズムの重要性を 認識することとなった。

満足して装用できるプリズム度数の平均值が 水平方向 $10 \Delta$ 、上下方向 $3 \Delta$ であること、プリ ズムに満足できる上下斜視角の範囲が $14 \Delta$ 以下 であり、実際に処方された上下方向のプリズム

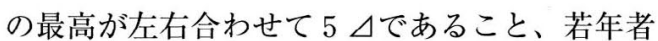
の上斜筋麻痺ではプリズムに満足しにくいこと などが明らかになった。これらの情報は今後プ リズム装用を勧める患者を選択する上で、参考 になると思われる。膜プリズム、組み込みプリ ズムの特性を熟知したうえで、一例一例丁寧に 対応することが処方の近道と考える。

\section{参考文献}

1) 清水みはる, 菅澤 淳, 中村桂子, 澤ふみ子, 渡邊敏夫，池田恒彦：成人の複視に対するフ レネル膜プリズムの処方. 日本弱視斜視学会 雑誌 $29 ： 35-38,2002$.

2 ) 高木満里子：複視に対する光学的治療 プリ ズム治療. 日視会誌 $31 ： 67-73 ， 2002$

3 ) Suzanne Veronneau-Troutman, 不二門 尚, 斎藤純子訳：プリズムと斜視. 文光堂, 東京, 1998.

4 ）馬嶋 孝：フレネル膜プリズムとそれによる Orthoptics. 眼臨 $67: 16-22,1973$. 